DOI: https://doi.org/10.24127/ajpm.v8i1.1739

\title{
PENDEKATAN TEORI BELAJAR ANDRAGOGI TERHADAP KEMAMPUAN MENYELESAIKAN SOAL MATEMATIKA DITINJAU DARI GENDER
}

\author{
Yuni Rosania ${ }^{1}$, Mujib ${ }^{2}$, Fraulein Intan $\mathrm{Suri}^{3}$ \\ ${ }^{1,2,3}$ Pendidikan Matematika, Universitas Islam Negeri Raden Intan Lampung \\ E-mail: $\quad$ yunirosania29@gmail.com ${ }^{1)}$ \\ mujibzahra@gmail.com ${ }^{2}$ \\ frauleinintan@radenintan.ac.id ${ }^{3)}$
}

Received 18 December 2018; Received in revised form 1 April 2019; Accepted 3 May 2019

\begin{abstract}
The purpose of this study was to see the effect of the andragogical learning theory approach on students' ability to solve mathematical questions in terms of student gender. This type of research is a quantitative study with an experimental method. The population of this study was all class X of SMA N 14 Bandar Lampung Academic Year 2018/2019. The sampling technique in this study used cluster random sampling. The analysis technique used in this study is a two-way variance analysis with cells not equal to a significant level of 5\%. Based on the results of two-way variance analysis with unequal cells, it was found that: (1) there was an influence of andragogical learning theory approach on students 'ability to solve mathematical questions, (2) there was a gender influence on students' ability to solve math problems, (3) there was no interaction between andragogical learning theory approach with gender on students' ability to solve math problems.
\end{abstract}

Keywords: Approach to Theory of Learning Andragogy; Gender; The ability to solve math problems.

\section{PENDAHULUAN}

Perkembangan

ilmu pengetahuan dan teknologi mencakup peningkatan ilmu terapan dan ilmu pengetahuan dasar. Salah satu upaya meningkatkan kemampuan penguasaan ilmu pengetahuan dasar adalah dengan meningkatkan kemampuan dalam bidang matematika (Farida, 2015). Matematika merupakan salah satu pelajaran yang sangat penting, dalam mempelajari matematika diharapkan peseta didik bukan hanya mengerti, tetapi paham dengan apa yang dia pelajari (Rizta \& Antari, 2018). Paham berarti peserta didik mampu untuk menyelesaikan masalah sehari-hari dalam model matematika, sehingga peserta didik harus dibekali dengan keterampilan kemampuan (Wijayanti, 2018)
Namun kenyataan di lapangan, kemampuan matematis peserta didik masih tergolong masih sangat rendah. Dalam penelitian Novianti, (2017) mengungkapkan bahwa kemampuan peserta didik dalam memecahkan masalah soal matematika masih belum memberikan kabar gembira yaitu dalam pra risetnya mengungkapkan bahwa peserta didik butuh mengulang-ulang membaca permasalahan setidaknya 5-6 kali sehingga akan memakan waktu pengerjaan yang diberikan dalam menyelesaikan masalah yang dihadapi. Selain itu (Lasmiyati \& Harta, 2014) kamampuan peserta didik dalam memahami konsep matematis masih perlu ditingkatkan lagi. Menurut Amin (2016) hasil belajar matematika peserta didik masih dibawa rata-rata. Berdasarkan beberapa paparan diatas maka dapat disimpulkan bahwa 
kemampuan penyelesaian soal matematika peserta didik masih dangat rendah.

Permasalahan ini juga ditemui juga pada hasil observasi yang dilakukan oleh peneliti di SMAN 14 bandar lampung dengan hasil bahwa kemampuan siswa menyelesaikan soal matematika di SMAN 14 Bandar Lampung masih di bawah rata-rata. Hal ini dapat dilihat pada dokumnetasi hasil ulangan harian peserta didik yaitu sebanyak 150 peserta didik dari 192 dari peserta didik yang didobservasi dari 6 kelas masih dibawah KKM dengan KKM >73. Dari data tersebut, siswa yang mendapat nilai di atas KKM didominasi oleh peserta didik perempuan peserta didik. Dengan presentase pada Gambar 1.

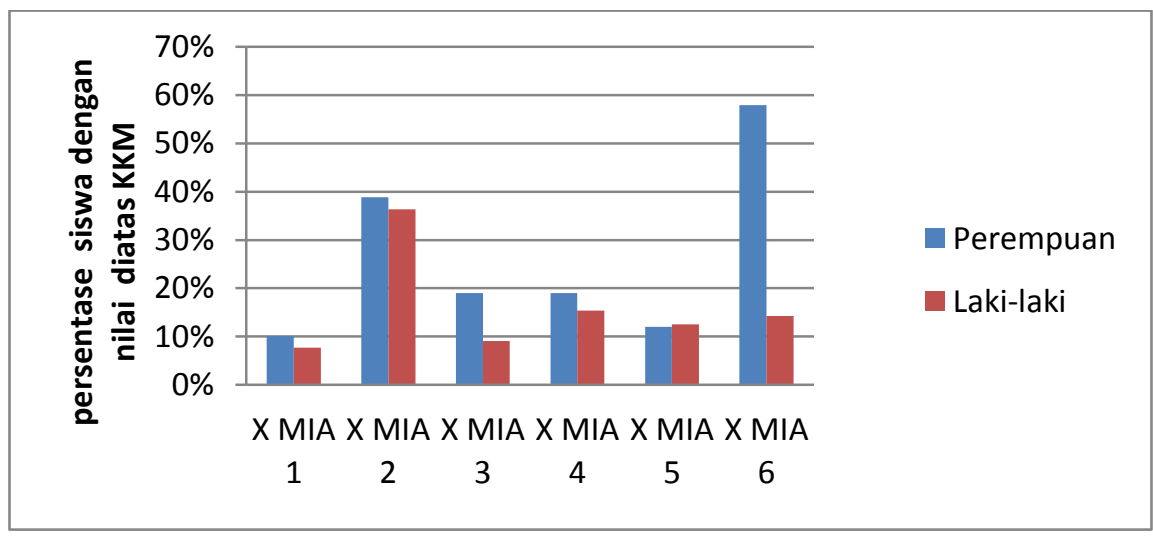

Gambar 1. Persentase hasil ulangan harian berdasarkan gender.

Berdasarkan Gambar 1. terdapat 5 kelas yang persentase nilai siswa perempuan lebih besar dari siswa lakilaki, hanya satu kelas yang persentase laki-laki lebih tinggi dari perempuan. Jika di buat persentase keseluruhan maka diperoleh persentase laki-laki yang mendapat nilai di atas KKM sebesar 15,71 \% dan perempuan sebesar 25\%.Dapat disimpulkan nilai di atas KKM didominasi oleh siswa perempuan. Jadi, grafik tersebut menunjukan terdapat perbedaan struktur kognitif perempuan dan lakilaki. Menurut Zubaidah (2013) bahwa karakteristik pembelajaran orang dewasa sangat memperhatikan faktor motivasi, minat, pengalaman belajar siswa, tingkat kecerdasan, dan bakat siswa faktor-faktor tersebut merupakan faktor psikologis dalam belajar. Faktor psikologis yang dimiliki setiap anak berbeda-beda, terutama antar laki-laki dengan perempuan. Perbedaan gender tersebut tentu menyebabkan perbedaan fisiologis dan mempengaruhi perbedaan psikologis dalam belajar siswa, sehingga siswa laki-laki dan perempuan tentu memiliki banyak perbedaan dalam mempelajari matematika.

Menanggapi rendahmya hasil belajar matematika dan perbedaan hasil belajar matematika berdasarkan gender ini beberapa penelitian telah mengungkapkan sebab musabab terjadinya permasalahan ini. Menurut Mujib (2015) dalam penelitiannya mengungkapkan bahwa dalam belajar matematika penggunaan teori belajar akan mempengaruhi kreatifitas peserta didik dalam belajar matematika. Selain itu diungkapkan pula Salah satu masalah yang dihadapi dunia pendidikan adalah masalah lemahnya proses pembelajaran. Proses pembelajaran di dalam kelas lebih 
banyak diarahkan kepada kemampuan menghafal tanpa dituntut untuk memahami, akibatnya siswa sulit menerapkan/mengaplikasikan teori yang diperoleh. Menurut Irawan \& Febriyanti (2016) penggunaan model pembelajaran yang tepat dalam sebuah pokok bahasan tertentu dapat meningkatkan hasil belajar matematika peserta didik menjadi lebih baik. Menurut Oktavianti, Farida, \& Putra (2018) penggunaan model pembelajaran dengan menggunakan teori belajar dapat meningkatkan kemampuan pemecahan masalah matematis peserta didik. Menurut Widyastuti (2015) dengan menggunakan teori belajar matematika dalam penelitiannya mengungkapkan bahwa Setiap siswa dalam menyelesaikan masalah matematika memiliki cara yang berbeda-beda sesuai dengan karakteristiknya masingmasing. Seseorang dapat menyelesaikan atau memecahkan masalah yang ada dengan baik apabila didukung oleh kemampuan menyelesaikan masalah yang baik pula. Kemampuan yang dimiliki seseorang untuk mengubah dan mengolah suatu permasalahan atau kesulitan yang terjadi dalam hidupnya dan menjadikan masalah tersebut menjadi suatu tantangan yang harus diselesaikan dengan sebaik-baiknya dikenal dengan Adversity Quotient (AQ). Berdasarkan beberapa penelitian tersebut maka dapat disimpulkan bahwa penggunaan teori belajar dalam belajar matematika dapat mempengaruhi kemampuan matematis peserta didik diantaranya kemampuan menyelesaikan soal matematika. Namun dalam peneleitian tersebut belum pernah melakukan penelitian menggunakan teori belajar matematika dalam benar-benar memperhatikan fenomena yang terjadi yaitu perbedaan hasil belajar berdasarkan gender.

Dalam penelitian ini teori belajar yang akan digunakan oleh peneliti adalah teori Andragogi. Karena adalah salah satu dari beberapa teori belajar yang cocok untuk pengajaran matematika humanis, karena sangat menitikberatkan pada pengalamanpengalaman yang didapat oleh peserta didik dalam kehidupan sehari-hari. Hal ini sesuai dengan karakteristik siswa dewasa, individu yang berumur lebih dari 16 tahun dapat dikatakan sebagai orang dewasa (Anggoro, 2016). Selain itu menurut Raharjo \& Suminar (2016) yang diungkap secara ulas mengungkapkan bahwa Andragogi menempatkan orang dewasa dalam layanan pendidikan yang bersifat demokratis, bertumpu kepada kesejajaran, kesepadanan dan persamaan perilaku kegiatan belajar. Dengan demikian andragogi adalah proses pembelajaran yang dapat membantu orang dewasa menemukan dan menggunakan hasil temuannya yang berkaitan dengan lingkungan sosial, adanya interaksi dan saling pengaruh antara tutor dengan peserta didik, sehingga dilakukan sebuah penelitian dengan tujuan melihat pengaruh teori androdogi terhadap kemampuan penyelesaian soal matematika peserta didik.

\section{METODE PENELITIAN}

Penelitian ini dilakukan di di SMAN 14 Bandar Lampung peserta didik kelas X. JENIS Penelitian ini adalah adalah penelitian eksperimen (Quasi Eksperimental Design) dengan rancangan desain faktorial $2 \times 2$. Kedua analisis data dilakukan untuk mendapatkan gambaran hasil belajar ditinjau dari perbedaan pendekatan teori belajar pembelajaran dan gender siswa. 
DOI: https://doi.org/10.24127/ajpm.v8i1.1739

Tabel 1. Rancangan Desain Penelitian

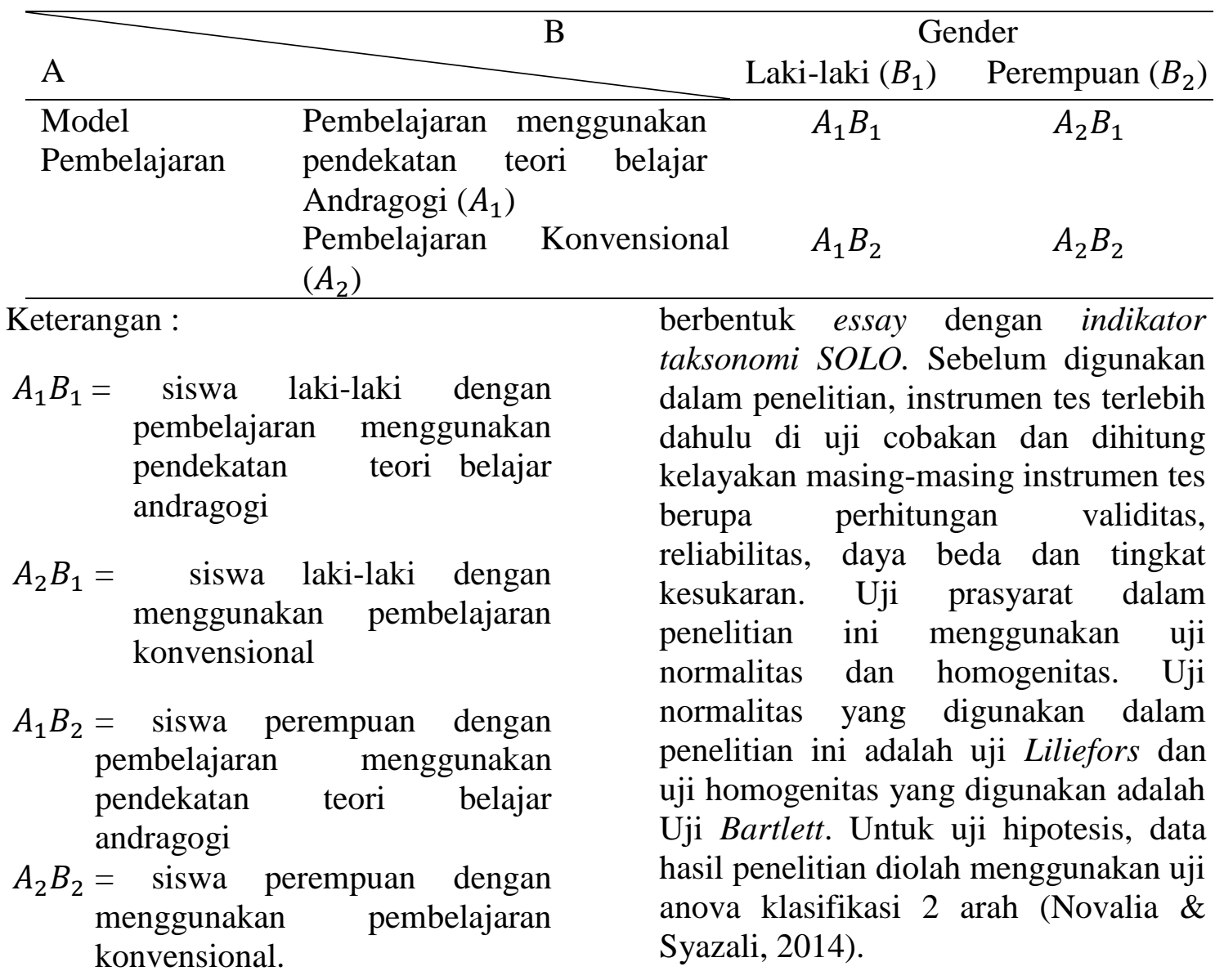

Teknik pengambilan sampel menggunakan Cluster Random Sampling (Area Sampling). Pada penelitian ini sampel yang akan diambil 2 kelompok dimana satu kelompok siswa yang tergabung dalam kelompok eksperimen, yaitu pembelajaran menggunakan pendekatan teori belajar andragogi. Satu kelompok tergabung dalam kelompok kelas kontrol menggunakan pembelajaran konvensional. Instrumen penelitian yang digunakan adalah instrumen tes

\section{HASIL PENELITIAN DAN PEMBAHASAN}

Setelah data hasil tes kemampuan pemahaman konsep peserta didik terkumpul baik dari kedua kelas eksperimen maupun kelas kontrol maka diperoleh: 
DOI: https://doi.org/10.24127/ajpm.v8i1.1739

Tabel 2. Deskripsi Amatan Hasil Belajar Matematika Peserta Didik

\begin{tabular}{lccccccc}
\hline \multicolumn{1}{c}{ Kelas } & $\boldsymbol{X}_{\text {maks }}$ & $\boldsymbol{X}_{\min }$ & \multicolumn{6}{c}{ Ukuran Tendensi Sentral } & \multicolumn{2}{c}{$\begin{array}{c}\text { Ukuran Variansi } \\
\text { Kelompok }\end{array}$} \\
\cline { 5 - 8 } & & & $\overline{\boldsymbol{X}}$ & $\boldsymbol{M e}$ & $\boldsymbol{M o}$ & $\boldsymbol{R}$ & $\boldsymbol{S}$ \\
\hline Eksperimen & 100 & 60 & 82,193 & 80 & 80 & 40 & 10,725 \\
Kontrol & 100 & 56 & 72,689 & 72 & 72 & 44 & 9,262
\end{tabular}

Berdasarkan Tabel 2 deskripsi amatan hasil belajar matematika peserta didik pada kelas eksperimen diperoleh nilai tertinggi 100 dan terkecil 60 , sehingga diperoleh nilai rata-rata peserta didik 82,193. Pada kelas control diperoleh nilai tertinggi 100 dan nilai terkecil 56 sehingga nilai rata-rata peserta didik pada kelas control diperoleh 72,629. Berdasarkan hal dapat disimpulkan bahwa rata-rata nilai siswa kelas eksperimen lebih baik dibandingkan dengan kelas kontrol. Selanjutkan dilakukan uji pra syarat kemampuan mengerjakan soal matematika peserta diidk dengan uji normalitas dan homogenitas pada kelas eksperimen dan kela kontrol.

Tabel 3. Uji Normalitas Kemampuan Mengerjakan Soal Matematika

\begin{tabular}{lccc}
\hline \multicolumn{1}{c}{ Perlakuan } & $\boldsymbol{L}_{\text {hitung }}$ & $\boldsymbol{L}_{\text {tabel }}$ & Keputusan \\
\hline Eksperimen & 0,147 & 0,159 & normal \\
Kontrol & 0,156 & 0,161 & normal \\
Laki-laki & 0,171 & 0,173 & normal \\
Perempuan & 0,137 & 0,149 & normal \\
\hline
\end{tabular}

Tabel 3 menunjukan bahwa data kelas eksperimen diperoleh $L_{\text {hitung }}=$ 0,147 dan $L_{\text {tabel }}=0,159$ dengan taraf signifikan $\alpha=0,05$ sehingga dapat dilihat bahwa $L_{\text {hitung }}<L_{\text {tabel }}$, sehingga $H_{0}$ diterima. Demikian pula dengan hasil perhitungan data pada kelas kontrol menunjukan bahwa $H_{0}$ diterima. Pada data gender laki-laki diperoleh $L_{\text {hitung }}=0,171$ dan $L_{\text {tabel }}=0,173$, maka dapat dilihat bahwa $L_{\text {hitung }}<L_{\text {tabel }}$, sehingga $H_{0}$ diterima. Pada data gender perempuan diperoleh $L_{\text {hitung }}=0,137$ dan $L_{\text {tabel }}=0,149$ maka dapat dilihat bahwa $L_{\text {hitung }}<L_{\text {tabel }}$, sehingga $H_{0}$ diterima. Berdasarkan hal ini maka dapat disimpulkan bahwa data berdisitribusi normal.

Untuk mengetahui apakah kedua sampel memiliki variansi yang sama atau tidak, maka dilakukan uji homogenitas. Pada penelitian ini uji homogenitas yang digunakan adalah Uji Bartlett. Hasil perhitungan data homogenitas dapat dilihat pada tabel 4 . 
DOI: https://doi.org/10.24127/ajpm.v8i1.1739

Tabel 4. Uji Homogenitas kemampuan menyelesaikan soal matematika

\begin{tabular}{lccl}
\hline \multicolumn{1}{c}{ Kelas } & $\chi_{\text {hitung }}^{2}$ & $\chi_{\text {tabel }}^{2}$ & Kesimpulan \\
\hline $\begin{array}{l}\text { Eksperimen } \\
\text { Kontrol }\end{array}$ & 0,618 & 3,481 & Homogen \\
\hline
\end{tabular}

Pada Tabel 4 menunjukkan $\chi_{\text {hitung }}^{2}=0,618$ dan $\chi_{\text {tabel }}^{2}=3,481$, maka $\chi_{\text {hitung }}^{2}<\chi_{\text {tabel }}^{2}$ sehingga dapat disimpulkan bahwa sampel-sampel berasal dari variansi yang sama. Setelah data diyang diperoleh berdisitribusi normal dan berasal dari variansi yang sama, ma selanjutnya di lakukan pengujian hipotesis menggunakan uji statistik anova dua arah. Hasil analisis yang diperoleh dapat dilihat pada Tabel 5.

Tabel 5. ANAVA dua arah sel tak sama

\begin{tabular}{lrrrrrl}
\hline SK & \multicolumn{1}{c}{ JK } & db & \multicolumn{1}{c}{ KT } & $\boldsymbol{F}_{\text {hitung }}$ & $\boldsymbol{F}_{\text {tabel }}$ & kesimpulan \\
\hline Baris & 544,897 & 1 & 544,897 & 5,823 & 4,013 & $H_{0}$ ditolak \\
Kolom & 1353,354 & 1 & 1353,354 & 14,464 & 4,013 & $H_{0}$ ditolak \\
Interaksi & 68,720 & 1 & 68,720 & 0,734 & 4,013 & $H_{0}$ diterima \\
Galat & 5239,429 & 59 & 93,561 & & & \\
\hline
\end{tabular}

Total $7206,400 \quad 56$

Berdasarkan perhitungan pada Tabel 5, dapat disimpulkan bahwa :

a) $F_{A}=5.823$ dengan taraf signifikan $5 \%$ diperoleh $F_{\text {tabel }}=$ 4.013 sehingga $F_{A}>F_{\text {tabel }}$ maka $H_{0 A}$ ditolak, berarti terdapat pengaruh pendekatan teori belajar andragogi terhadap kemampuan menyelesaikan soal matematika kelas X di SMAN 14 Bandar Lampung.

b) $F_{B}=14.464$ dengan taraf signifikan $5 \%$ diperoleh $F_{\text {tabel }}=$ 4.013 sehingga $F_{B}>F_{\text {tabel }}$ maka $H_{0 B}$ ditolak, berarti terdapat Pengaruh perbedaan gender terhadap kemampuan menyelesaikan soal matematika kelas X di SMAN 14 Bandar Lampung.

c) $F_{A B}=0.734$ dengan taraf signifikan $5 \%$ diperoleh $F_{\text {tabel }}=$
4.013 sehingga $\quad F_{A B}<F_{\text {tabel }}$ maka $H_{0 A B}$ diterima, berarti tidak terdapat interaksi antara pendekatan teori belajar andragogi dengan gender terhadap kemampuan menyelesaikan soal matematika kelas X di SMAN 14 Bandar Lampung.

Pada penelitian ini tidak dilakukan uji komparasi ganda karena masing-masing perlakuan hanya memiliki dua kategori, penarikan kesimpulan dapat dilakukan melalui pengamatan rata-rata antar baris dan kolom. Hasil perhitungan untuk rataan dan rataan marginal telah terangkum pada Tabel 6. 
DOI: https://doi.org/10.24127/ajpm.v8i1.1739

Tabel 6. Rataan dan Rataan Marginal

\begin{tabular}{lcccc}
\hline \multirow{2}{*}{ Gender } & & \multicolumn{2}{c}{ Pendekatan Pembelajaran } & \multirow{2}{*}{$\begin{array}{c}\text { Rataan } \\
\text { Marginal }\end{array}$} \\
\cline { 3 - 4 } Laki-laki & $\mathbf{N}$ & Teori Andragogi & Konvensional & \\
& $\overline{\boldsymbol{x}}$ & 78,571 & 12 & \\
Perempuan & $\mathbf{N}$ & 17 & 69 & 73,785 \\
& $\overline{\boldsymbol{x}}$ & 85,176 & 17 & \\
\multicolumn{2}{l}{ Rataan Marginal } & 81,873 & 75,294 & 80,235 \\
\hline
\end{tabular}

Berdasarkan Tabel 6. Dapat dilihat bahwa gender laki-laki dengan pendekatan teori belajar andragogi memiliki rataan sebesar 78,571 dengan pendekatan konvensional memiliki rataan sebesar 69. Gender perempuan dengan pendekatan teori belajar andragogi memiliki rataan sebesar 85,176 dengan pendekatan konvensional memiliki rataan 75,294. Perhitungan rataan marginal menggunakan teori andragogi sebesar 81,873 sedangkan rataan marginal menggunakan pendekatan konvensional sebesar 72,147. Perhitungan rataan marginal pada gender laki-laki sebesar 73,783 sedangkan rataan marginal pada gender perempuan sebesar 80,235. Berdasarkan hal ini dapat disimpulkan bahwa kelas eksperimen memperoleh hasil evaluasi yang lebih baik dibandingkan kelas kontrol. Hal tersebut dikarenakan dalam teori belajar belajar andragogi memuat prinsip-prinsip pembelajaran yang menuntut siswa untuk lebih aktif dalam proses pembelajaran dikelas. Selain itu dikarenakan teori androdogi, guru lebih difokuskan dalam menjaga dan mengarahkan proses pembelajaran yang dilakukan didalam kelas. Hasil penelitian ini sama dengan hasil penelitian sebelumnya. Berdasarkan hasil penelitian Pada penelitian ini (Rahman \& safitri Elshap, 2018) yang menyatakan bahwa proses pembelajaran yang menggunakan pendekatan andragogi memberikan dampak yang cukup besar dalam membangun motivasi belajar.

Selain itu pada penelitian Afandi (2016) mengungkapkan bahwa perempuan lebih unggul dalam ketepatan, ketelitian, kecermatan, dan keseksamaan berpikir membuat siswa perempuan lebih unggul dalam menyelesaikan soal matematika terutama soal dengan indikator extended abstract dan relational. Karena dengan ketepatan, ketelitian, kecermatan, dan keseksamaan berpikir, jawaban dari penyelesaian soal lebih terperinci dan jelas. Dibandingkan siswa laki-laki yang kurang teliti dalam menyelesaikan soal, sehinggga banyak melakukan perhitungan yang salah.

\section{KESIMPULAN DAN SARAN}

Berdasarkan hasil analisis, pengolahan data, pembahasan dan penelitian mengenai pengaruh pendekatan teori belajar andragogi terhadap kemampuan siswa menyelesaikan soal matematika ditinjau dari gender kelas $\mathrm{X}$ di SMAN 14 Bandar Lampung, dapat disimpulkan bahwa terdapat pengaruh pendekatan teori belajar andragogi terhadap kemampuan menyelesaikan soal matematika, terdapat pengaruh gender terhadap kemampuan menyelesaikan soal matematika dan tidak terdapat interaksi antara pendekatan teori belajar andragogi dengan gender terhadap 
DOI: https://doi.org/10.24127/ajpm.v8i1.1739

kemampuan menyelesaikan soal matematika

Berdasarkan kesimpulan dari hasil penelitian, beberapa hal yang disarankan bagi peneliti lain dalam pengembangan ilmu pengetahuan mengenai pendekatan yang digunakan dalam pembelajaran yaitu peneliti selanjutnya dapat mengubah variabel moderator gender dengan SelfCofidence untuk mengetahui variabelvariabel yang dapat memperkuat atau memperlemah variabel dependen. Peneliti selanjutnya dapat menerapkan teori belajar andragogi untuk meningkatkan kemampuan matematika lainnya.

\section{DAFTAR PUSTAKA}

Afandi, A. (2016). Profil Penalaran Deduktif Siswa SMP Dalam Menyelesaikan Masalah Geometri Berdasarkan Perbedaan Gender. APOTEMA: Jurnal Program Studi Pendidikan Matematika, 2(1), 8-21.

Amin, M. (2016). Pengaruh Mind Map dan Gaya Belajar terhadap Hasil Belajar Matematika Siswa. Tadris: Jurnal Keguruan Dan Ilmu Tarbiyah, 1(1), 85-92.

Anggoro, B. S. (2016). Analisis Persepsi Siswa SMP terhadap Pembelajaran Matematika ditinjau dari Perbedaan Gender dan Disposisi Berpikir Kreatif Matematis. Al-Jabar: Jurnal Pendidikan Matematika, 7(2), 153-166.

Farida, N. (2015). Analisis kesalahan siswa SMP kelas VIII dalam menyelesaikan masalah soal cerita matematika. AKSIOMA:
Jurnal Program Studi
Pendidikan Matematika, 4(2).

Irawan, A., \& Febriyanti, C. (2016). Efektifitas Mathmagic dalam Peningkatan Hasil Belajar Matematika. Formatif: Jurnal Ilmiah Pendidikan MIPA, 6(1).

Lasmiyati, L., \& Harta, I. (2014). Pengembangan Modul Pembelajaran untuk Meningkatkan Pemahaman Konsep dan Minat SMP. Pythagoras: Jurnal Pendidikan Matematika, 9(2), 161-174.

Mujib, M. (2015). Membangun kreativitas siswa dengan teori schoenfeld pada pembelajaran matematika melalui lesson study. Al-Jabar: Jurnal Pendidikan Matematika, 6(1), 30-42.

Novalia, M. S., \& Syazali, M. (2014). Olah Data Penelitian Pendidikan. Bandar Lampung: Anugrah Utama Rahaja.

Novianti, D. E. (2017). Profil Pemecahan Masalah Matematika Dalam Menyelesaikan Permasalahan Pemrograman Linear Ditinjau Dari Kemampuan Komunikasi Matematis Mahasiswa. JIPM (Jurnal Ilmiah Pendidikan Matematika), 6(1), 53-59.

Oktavianti, S., Farida, F., \& Putra, F. G. (2018). Implementasi Model Osborn Dengan Teknik Mnemonic Melalui Teori Konstruktivisme Terhadap Kemampuan Pemecahan Masalah Matematis. MaPan: Jurnal Matematika dan Pembelajaran, 6(1), 94-103. 
DOI: https://doi.org/10.24127/ajpm.v8i1.1739

Raharjo, T. J., \& Suminar, T. (2016). Penerapan Pedagogi dan Andragogi pada Pembelajaran Pendidikan Kesetaraan Kelompok Belajar Paket A, B, dan C di Kota Semarang. Edukasi, 1(1).

Rahman, A., \& safitri Elshap, D. (2018). Implementasi Kekuatan Motivasi Belajar Dalam Pendekatan Andragogi. Empowerment, 5(2), 1-12.

Rizta, A., \& Antari, L. (2018). Pengembangan Tes Kemampuan Komunikasi Matematis Pada Materi Sistem Persamaan Linear Untuk Mahasiswa Calon Guru Matematika. AKSIOMA: Jurnal Program Studi Pendidikan Matematika, $\quad 7(2), \quad 291$. https://doi.org/10.24127/ajpm.v7 i 2.1525
Widyastuti, R. (2015). Proses berpikir siswa dalam menyelesaikan masalah matematika berdasarkan teori Polya ditinjau dari adversity quotient tipe climber. Al-Jabar: Jurnal Pendidikan Matematika, 6(2), 183-194.

Wijayanti, D. (2018). Analisis Soal Pemecahan Masalah pada Buku Sekolah Elektronik Pelajaran Matematika SD/MI. Majalah Ilmiah Sultan Agung, 49(123), 27-39. 